\title{
A Directory to International LIS Education Accreditation \\ Processes: Part III
}

\author{
Xiaoai Ren \\ The Department of Library and Information Studies, Valdosta State University, Valdosta, \\ Georgia, USA
}

We will continue to look at LIS education accreditation processes across the world in Part III of this directory. This time, readers will find information on the accreditation processes for LIS education in New Zealand. Any new LIS education programs and degrees offered by universities in New Zealand, or any significant changes made to the existing structure of LIS education programs in New Zealand universities must get approval from the Committee on University Academic Programmes (CUAP). The Library and Information Association of New Zealand Aotearoa (LIANZA) assesses the LIS education providers in New Zealand on their coverage of the body of knowledge regularly.

Approving Agency - Committee on University Academic Programmes (CUAP)

(https://www.universitiesnz.ac.nz/about-universities-new-zealand/unz-committees-andworking-groups/committee-university-academic)

The New Zealand Vice-Chancellors' Committee (now called Universities New Zealand) is the statutory body under the 1989 Education Act with primary responsibility for the university sector's quality assurance matters. Universities NZ has delegated its powers to the Committee on University Academic Programmes (CUAP). Its main functions include programme approval and accreditation. CUAP meets twice a year (usually July and November) to consider proposals by universities for new degree programs or major changes to existing ones, as well as additional meeting to action a range of academic matters. Proposals for a new program or for a major change to an existing program submitted to CUAP are subject to a peer review process. Without approval from CUAP, no new or significantly modified programmes will be funded by the Tertiary Education Commission (http://www.tec.govt.nz/). 
The Library and Information Association of New Zealand Aotearoa (LIANZA) introduced the individual Professional Registration scheme in 2007. The scheme provides an assurance that registered library and information professionals meet professional standards of competency in their body of knowledge and understand the ethics required for library and information work. The eligible applicants must meet certain requirements by obtaining a recognized degree at undergraduate level or higher; applying the body of knowledge practically in a library and information environment, and be a current member of one of several specified library and information management associations.

The LIANZA Professional Registration Board (PR Board) is responsible for assessing the LIS education providers, developing standards and criteria, and reviewing incoming applications. The Board consists of at least eight members. It is a team of experienced library and information professionals. Each board member is appointed for an initial term of three years.

The LIANZA PR Board conducts regular reviews of New Zealand LIS degree education providers a minimum of every five years, or as needed when a degree program is significantly updated or revised. The review is led by a member of the PR Board and carried out by a panel appointed for this task. Two or three reviewers form a Review Panel for undertaking the reviews. At least one reviewer remains on the Review Panel for the next review to ensure continuity of the assessment process. The Review Panel assesses the knowledge coverage of the curriculum and determine whether the curriculum meets the professional registration scheme, and thereby comply with the LIANZA professional registration program. The PR Board is responsible for ratifying the Recommendations of the Review Panel.

\section{LIS Education Providers Recognized by LIANZA (https://lianza.org.nz/node/282)}

LIANZA recognizes the following LIS degrees in New Zealand

- Master of Information Studies (MIS) with the Libraries Specialization (LIBS) - Victoria University of Wellington

- Bachelor of Applied Science with Information and Library Studies (ILS) major - Open Polytechnic of New Zealand

- Bachelor of Arts with ILS major or double major with ILS / Humanities or ILS / Communication - Open Polytechnic of New Zealand

- Bachelor of Library and Information Studies - Open Polytechnic of New Zealand

- Other New Zealand graduate qualifications may be approved by the PR Board if linked to a related discipline (such as information technology (IT), information studies (IS), archives, records management, or Maori information management) where these qualifications can be mapped against the body of knowledge

LIANZA also recognizes overseas degrees recognized by the following library associations:

- Chartered Institute of Library \& Information Professionals in the United Kingdom (CILIP)

- Australian Library \& Information Association (ALIA) 
- American Library Association (ALA)

- Canadian Library Association (CLA)

Individuals with LIANZA recognized LIS degrees are eligible to apply to the Professional Registration Scheme. Applicants who hold a LIANZA recognized degree with three years of work experience are automatically granted professional registration. All registered library and information professionals must renew their registration every three years by documenting annual professional development activities. Registered individuals may apply for an extension for up to 12 months.

\section{Professional Registration Process}

To gain registration, one must:

1. Join LIANZA or an affiliated organization

2. Hold a recognized degree

3. Complete application form

4. Map experience against Body of Knowledge (unless holding a degree from one of the recognized New Zealand LIS education providers)

5. Attach CV and transcripts

6. Email application and all relevant documents

7. Receive confirmation of application

8. Pay fees for entry to the Professional Registration scheme and for ongoing membership.

Bodies of Knowledge (BoK) (https://lianza.org.nz/professional-registration/bodies-knowledge)

The Bodies of Knowledge (BoK) identify the different areas of competency for the Library and Information Profession. There are six clusters of 11 BoKs. The PR Board reviews BoKs annualy to ensure it is still fit for purpose.

\begin{tabular}{|l|l|}
\hline Clusters & BoKs \\
\hline $\begin{array}{l}\text { BOK Cluster 1: Understanding the } \\
\text { information environment }\end{array}$ & BoK 1 Information Environment, Information \\
& Policy \& Ethics \\
\hline
\end{tabular}




\begin{tabular}{|c|c|}
\hline $\begin{array}{l}\text { BOK Cluster 2: Understanding information } \\
\text { needs, generations and access }\end{array}$ & $\begin{array}{l}\text { BoK } 2 \text { Generating, Communicating \& Using } \\
\text { Information } \\
\text { BoK } 3 \text { Information Needs \& Design } \\
\text { BoK } 4 \text { The information Access Process }\end{array}$ \\
\hline $\begin{array}{l}\text { BOK Cluster } 3: \text { Understanding information } \\
\text { resource and knowledge management }\end{array}$ & $\begin{array}{l}\text { BoK } 5 \text { Organisation, Retrieval, Preservation } \\
\text { and Conservation } \\
\text { BoK } 8 \text { Information Resource Management and } \\
\text { Knowledge Management }\end{array}$ \\
\hline $\begin{array}{l}\text { BOK Cluster 4: Understanding information } \\
\text { and communication technologies }\end{array}$ & $\begin{array}{l}\text { BoK } 7 \text { Application of Information and } \\
\text { Communication Technologies (ICTs) }\end{array}$ \\
\hline $\begin{array}{l}\text { BOK Cluster } 5: \text { Understanding management } \\
\text { in information organisations }\end{array}$ & $\begin{array}{l}\text { BoK } 6 \text { Research, Analysis and Interpretation } \\
\text { of Information } \\
\text { BoK } 9 \text { Management in Information } \\
\text { OrganisationsEffectiveness }\end{array}$ \\
\hline $\begin{array}{l}\text { BOK Cluster } 6: \text { Understanding Maori } \\
\text { knowledge paradigms }\end{array}$ & $\begin{array}{l}\text { BoK } 11 \text { Awareness of Indigenous Knowledge } \\
\text { Paradigms }\end{array}$ \\
\hline
\end{tabular}

\section{Conclusion}

Part III of the A Directory to International LIS Education Accreditation Processes concludes the series of reports on the LIS education accreditation processes around the world. Part I includes information about the LIS education accreditation in North America, UK, and Australia. Part II introduces LIS education accreditation in Ireland, Germany, and South Africa. Part III is about the LIS education accreditation in New Zealand. We identified three LIS education accreditation 
processes by synthesizing findings from these countries. They are accreditation done by professional association; accreditation done by government organization; and a parallel accreditation done by both professional association and government organization with professional organization focusing on reviewing the LIS program from the professional perspective, and the government organization focusing on reviewing the LIS program from higher education quality assurance perspective. Many countries still do not have a formal LIS education accreditation process in place at this time.

\section{Acknowledgement}

The series on LIS education accreditation processes around the world would not have been completed without the generous support and help from LIS educators and professionals around the world. I want to thank Cathal McCauley, the Maynooth university librarian for explaining to me the LIS education accreditation done by the Library Association of Ireland (LAI) in Ireland. I thank Dr. Michael Seadle from Berlin School of Library and Information Science, Dr. Achim Oßwald and his colleague Susanne Röltgen from TH Köln for communicating with me via emails on the LIS education accreditation system in Germany. I would also like to thank LIASA President Nikki Crowster and LIASA Manager Annamarie Goosen for providing information on LIS education accreditation in South Africa. Finally yet importantly, I want to thank Joanna Matthew, Jess Davidson, Marney Kaka, Jaimee Murdoch, Jan Irvine, and Jennifer Campbell-Meier for their generous support on helping me find information about LIS education accreditation in New Zealand.

\footnotetext{
About the author

Dr. Xiaoai Ren is an Associate Professor in the Master of Library and Information Science program at Valdosta State University. This is a fully online program. Dr. Ren teaches reference course. She holds an M.S. in Information Management from Peking University and a Ph.D. in Information Science from the University at Albany - State University of New York. Her research interests include library cooperation at regional, national, and international levels, reference services, international librarianship, and eBooks in libraries.
} 